\title{
Characterization of Biodiesel Produced from Jatropha Curcas Oil via Acid/Base Catalyzed Transesterification
}

\author{
VISHAV DEEPAK SONIA ${ }^{1}$, ANIL KUMAR BHADANA ${ }^{2}$ and GAJENDRA KUMAR ${ }^{3 *}$ \\ ${ }^{1}$ Department of Chemistry, Mewar University Chittorgarh-312001, Rajasthan, India \\ ${ }^{2}$ Department of Chemistry, Venkateshwara University, Gajraula-244236, (UP) India \\ ${ }^{3}$ Chemical Science Laboratory, Department of Applied Science, \\ Bhagwant Institute of Technology, Muzaffarnagar-251315, Uttar Pradesh, India \\ gaj.chem@gmail.com
}

Received 23 January 2016 / Accepted 13 Febraury 2016

\begin{abstract}
Biodiesel, alkyl ester of vegetable oil is an environment friendly renewable non toxic biodegradable diesel fuel produced by the acid or base catalyzed methanolysis of vegetable oil. The optimized reaction conditions are molar ratio of oil to $\mathrm{MeOH} 1: 6$, reaction temperature $65{ }^{\circ} \mathrm{C}$ and reaction time 35 minute higher catalyst percentage significantly increased reaction rate and production capacity. The maximum catalyst concentration $1.0 \mathrm{wt} \%$ of oil gives the best conversion $96 \pm 0.05 \%$. The biodiesel were characterized for their physical and fuel properties including density, viscosity, iodine volume, acid volume, cloud point, pure point, gross heat of combustion and volatility (ASTM). The purity and conversion of the biodiesel was analyzed by HPLC.
\end{abstract}

Keywords: Jatropha curcas oil, Methanol, Base catalyst, Transesterification, HPLC

\section{Introduction}

Fossil fuels increases greenhouse gas emissions and cause global warming. Biodiesel is environmentally friendly liquid fuel similar to diesel in combustion properties. Increasing environmental concern, diminishing petroleum reserves and agriculture based economy of our country are the driving forces to promote biodiesel as an alternative fuel ${ }^{1}$. Other advantage of the biodiesel is its good lubrication properties, high cetane number, high flash point and acceptable cold filter plugging point (CFPP) which make it very attractive as a alternative fuel that extend the engine life ${ }^{2,3}$. The majority of the energy sources are supplied through petrochemical, coal and natural gases. Petrochemical energy is very important in the world, especially diesel, because this is the main fuel used for industrial and agricultural transportation. The huge energy demand in the industrialized world and the population problems caused due to the widespread use of fossil fuels, depletion of the world petroleum reserves and increasing environmental concerns has stimulate the search for renewable fuel and made it increasingly necessary to develop alternative sources of energy to resolve 
these question. Alternative diesel fuels must be acceptable, economically competitive, environmental friendly and easily available. From this view of point, the use of vegetable oil as alternative fuels for diesel engines is a promise in many countries. Different processes are currently available to achieve transesterification of oil for the production of fatty acid esters which include chemical or enzymatic catalyst and supercritical alcohol treatment ${ }^{4-7}$. A sustainable and economical supply of raw material is the key factor for the biodiesel production to be competitive commercially. An effective way to reduce production cost is by introducing cheap and non edible oils such as waste cooking oil, industrial fat, Jatropha curcas oil, Pongamia oil and animal fat ${ }^{8-10}$. Reactive extraction is another method to produced biodiesel. The conventional method where the oil is first extracted from the oil seed and then transesterification occurs. In the reactive extraction alcohol reacts as extractive solvent and as a reactant for transesterification where all the reactants including catalyst are mixed in one phase to get the higher yield of fatty acid ester. In the present article we study the catalytic action of $\mathrm{KOH}, \mathrm{NaOH}, \mathrm{CH}_{3} \mathrm{COONa}$ and enzyme catalyst for the transesterification of Jatropha curcas oil.

\section{Experimental}

Commercial grades Jatropha curcas oil was procured from local market purchase, $\mathrm{MeOH}$ (purity 98\%), $\mathrm{H}_{2} \mathrm{SO}_{4}, \mathrm{NaOH} \mathrm{KOH}$ were purchased from M/S Ranbaxy and lipase from E. aerogenes ${ }^{11}$. The acid value of the Jatropha curcas oil was $5.4 \mathrm{mg} \mathrm{KOH} / \mathrm{g}$ sample $(0.5 \mathrm{mg}$ $\mathrm{KOH} / \mathrm{g}$ sample after pretreatment). Initial composition of oil analyzed by HPLC was Triglycerides (TG) $94.5 \mathrm{wt} \%$, Diglycerides (DG) $4.5 \mathrm{wt} \%$ and monoglycerides (MG) $1.0 \mathrm{wt} \%$.

\section{Transesterification of Jatropha curcus oil}

The experiment was carried out in a batch type reactor. The preparation of biodiesel from Jatropha curcus oil involves base and acetic catalyzed transesterification with methanol to give methyl esters. The molar ratio of oil to methanol 1:6 was used in the reaction. After completion of the reaction, the reaction mixture was transferred into a rotarvapour flask to recover unreacted $\mathrm{MeOH}$ and then filter for the separation of catalyst. The filtrate was transferred into a separating funnel for phase separation. The ester mixture formed the upper layer and the glycerol form in the lower layer. The traces of glycerol in ester layer were washed with hot water and the biodiesel dried over the anhydrous sodium sulphate.

\section{HPLC analysis}

HPLC was used to analyze the purity, conversion and Fatty acid methyl esters (FAMEs) composition of the biodiesel esters sample. The reverse phase high performance liquid chromatography (RP-HPLC) separates different components according to their polarity. The chromatographic apparatus consisted of a model waters 600 pump with waters 600 controller, waters 2,996 photodiode array detector, a nova-pack ${ }^{\circledR}, 3.9 \times 150 \mathrm{~mm}$ column with guard column of dimension $3.9 \times 20 \mathrm{~mm}$, both packed with C18 particle with diameter $4 \mu \mathrm{m}$ (all from waters, Milford MA, USA).

HPLC condition: RP-HPLC method flow rate of $1 \mathrm{~mL} / \mathrm{min}$, an injection volume of $5 \mu \mathrm{L}$, a column temperature of $45^{\circ} \mathrm{C}$, the UV detection at $215 \mathrm{~nm}$ and a 40 min gradient mobile phase $15 \% \mathrm{H}_{2} \mathrm{O}+85 \% \mathrm{CH}_{3} \mathrm{OH}$ in $10 \mathrm{~min}, 100 \% \mathrm{CH}_{3} \mathrm{OH}$ in 0 min, $60 \% \mathrm{CH}_{3} \mathrm{OH}+15 \%$ hexane + $25 \%$ propane-2-ol in $30 \mathrm{~min}$ and for the last 10 min system back to initial state $15 \% \mathrm{H}_{2} \mathrm{O}+$ $85 \% \mathrm{CH}_{3} \mathrm{OH}$ were used for the separation and determination of the compound produced during the methanolysis of Jatropha curcas oil in all the experiments ${ }^{12,13}$. 
Kinematic viscosity, acid number and oxidation stability

All the physicochemical properties are given in Table 1 . The kinematic viscosity of biodiesel at $40{ }^{\circ} \mathrm{C}$ was determined followed by ASTM D 445 using a Rheotek AKV 800 automated kinematic viscometer (Poulten Selfe and Lee Ltd., Essex, England). The acid number of biodiesel was determined according to ASTM D 664 using a Brinkman/Metrohn 809 Titrando (Westbury, NY). The oxidation stability of biodiesel was determined as the induction period (IP) according to EN 14112 using a Metrohn 743 Rancimat instrument (Herisau, Switzerland).

\section{Cold flow properties}

The cloud point (CP), pour point (PP) and cloud filter plugging point (CFPP) measurements were determined as per ASTM standers D 2500-05, D 97-96a and D 6371-05, respectively. A Lawler model DR-34H automated cold properties analyzed (Lawler Manufacturing Corporation, Edison, $\mathrm{NJ}$ ) was used to measure the cold flow properties.

Table 1. Physicochemical characterization of Jatropha curcas biodiesel

\begin{tabular}{|c|c|c|c|c|}
\hline Property & $\begin{array}{l}\text { ASTM } \\
\text { method }\end{array}$ & $\begin{array}{c}\text { ASTM } \\
\text { Specification }\end{array}$ & $\begin{array}{c}\text { BIS } \\
\text { Specification }\end{array}$ & Biodiesel \\
\hline $\begin{array}{c}\text { Viscosity } 40^{\circ} \mathrm{C}, \\
\mathrm{mm}^{2} / \mathrm{s}\end{array}$ & D 445 & $1.9-6.0$ & $2.5-6.0$ & 3.88 \\
\hline $\begin{array}{l}\text { Acid number, } \\
\mathrm{mgKOH} / \mathrm{g}\end{array}$ & D 664 & 0.5 & $<0.5$ & 0.18 \\
\hline $\begin{array}{l}\text { Free glycerin, } \\
\text { mass } \%\end{array}$ & D 6584 & 0.020 & - & 0.008 \\
\hline $\begin{array}{l}\text { Total glycerin, } \\
\text { mass } \%\end{array}$ & D 6584 & 0.24 & - & 0.24 \\
\hline $\begin{array}{l}\text { Oxidation stability } \\
\text { (IP, h) }\end{array}$ & EN 14112 & 3 minimum & - & 5.0 \\
\hline Cloud point & D 2500-05 & -3 to +12 & - & -5 \\
\hline Pour point & D 97-96a & -15 to +10 & - & -12 \\
\hline Cetane number & D 613 & $>47$ & $>51$ & 54 \\
\hline $\begin{array}{l}\text { Cold filter plugging } \\
\text { point }\end{array}$ & D 6371 & -4 to -9 & - & -1 \\
\hline $\begin{array}{c}\text { Density at } 15{ }^{\circ} \mathrm{C} \\
\mathrm{kg} / \mathrm{mL}\end{array}$ & D 976 & 0.575 to 0.900 & $0.860-0.900$ & 0.8633 \\
\hline Flash point, ${ }^{\circ} \mathrm{C}$ & D 93 & $>100$ & $>120$ & 135 \\
\hline Carbon residue, wt $\%$ & D 4530 & $<0.02$ & $<0.02$ & 0.005 \\
\hline $\begin{array}{l}\text { Copper strip } \\
\text { corrosion, } \\
3 \mathrm{~h} \text { at } 100{ }^{\circ} \mathrm{C}\end{array}$ & D 6751 & $<$ No. 1.0 & 1.0 & 1.0 \\
\hline Water content, ppm & D 95 & $<500$ & $<500$ & 230 \\
\hline
\end{tabular}

\section{Results and Discussion}

Our investigation is based on using acid and base catalyst for biodiesel production in a conventional batch type reactor by transesterification of Jatropha curcas oil with methanol. The optimal reaction condition involved using 1:6 oil to $\mathrm{MeOH}$ ratio, catalyst percentage 1.0 wt.\% of oil, reaction time $35 \mathrm{~min}$ and reaction temperature $65{ }^{\circ} \mathrm{C}$. At these optimized condition we got the maximum yield $96 \%$ of biodiesel. 


\section{Catalyst type and concentration}

Catalyst used for the transesterification of vegetable oils are classified as alkali, acid, enzyme and heterogeneous catalysts, alkali catalysts like sodium hydroxide, potassium hydroxide and sodium methoxide are more effective. If the oil has high free fatty acid (FFA) and water sulphuric acid and heterogeneous acetic catalyst is suitable for transesterification. As a catalyst in the process of alkaline methanolysis mostly potassium hydroxide has been used when the oil has less than 1\% FFA.

In the present work transesterification of Jatropha curcas oil, we studied alkaline catalyst (sodium hydroxide, potassium hydroxide, sodium methoxide), acetic catalyst (sulphuric acid and enzyme catalyst). In the methanolysis of Jatropha curcas oil with potassium hydroxide gives the best results when catalyst concentration was $1.0 \mathrm{wt} \%$ of oil, temperature $65{ }^{\circ} \mathrm{C}$ and molar ratio oil to $\mathrm{MeOH} \mathrm{1:6,} \mathrm{Reaction} \mathrm{time} 35 \mathrm{~min}$. Figure 1 summarized the effects of catalyst type and variation in catalyst concentration from 0.25 to $1.0 \mathrm{wt} \%$ of oil. An advantage of potassium hydroxide catalyst, that it can be neutralized with phosphoric acid and the product of the neutralization reaction can be used as fertilizer ${ }^{14}$.

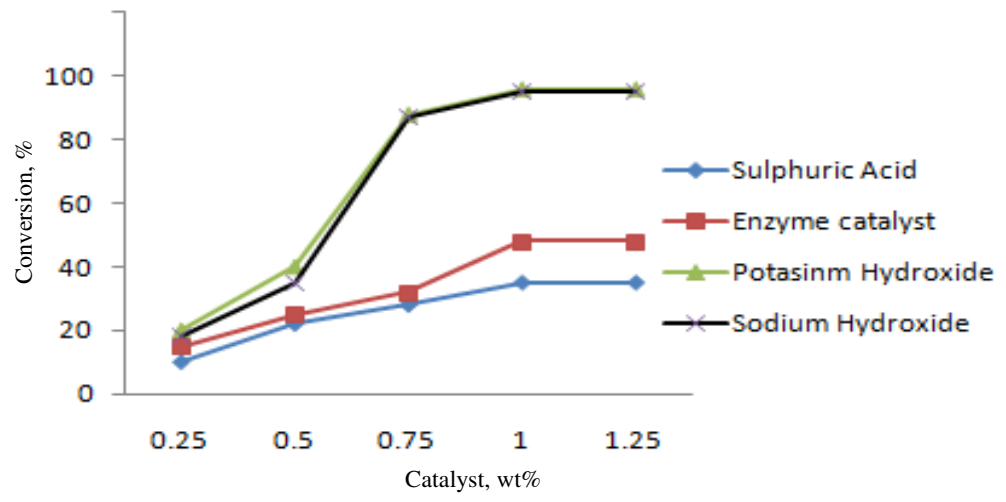

Figure 1. Effect of catalyst type and concentration on fatty acid methyl ester production with reaction temperature $65{ }^{\circ} \mathrm{C}$. (Molar ratio oil: methanol 1:6, reaction time $35 \mathrm{~min}$ )

\section{Effect of reaction time}

Experimental trials were carried out at temperature $65{ }^{\circ} \mathrm{C}$, molar ratio oil to methanol 1:6, catalyst concentration $1.0 \mathrm{wt} \%$ of oil. The sample was collected at different time interval after 20, 25, 30, 35 and $40 \mathrm{~min}$. The conversion of product was analyzed by HPLC. As shown in Figure 2 the conversion of Jatropha curcus oil into fatty acid methyl esters increased with reaction time. The maximum conversion $96 \%$ of biodiesel was observed after $35 \mathrm{~min}$.

\section{Effect of molar ratio}

Molar ratio of oil to methanol is one of the most important variables affecting the yield of fatty acid methyl ester. The stoichiometric ratio for transesterification requires three moles of alcohol and one mole of triglyceride to yield the three moles of fatty acid methyl esters and one mole of glycerol. However, transesterification is an equilibrium reaction in which a high molar ratio is used to drive the reaction to the right. Experiments were conducted with molar ratio of oil to methanol 1:3, 1:4, 1:5, 1:6 and 1:7. The optimum condition for batch process produce methyl ester has reaction time $35 \mathrm{~min}$ with catalyst concentration $1.0 \mathrm{wt} . \%$ of oil. Figure 3 indicates the results of these experiments. In the present work at the molar ratio 1:6 gave the best conversion $96 \%$ of triglycerides into fatty acid methyl esters. 


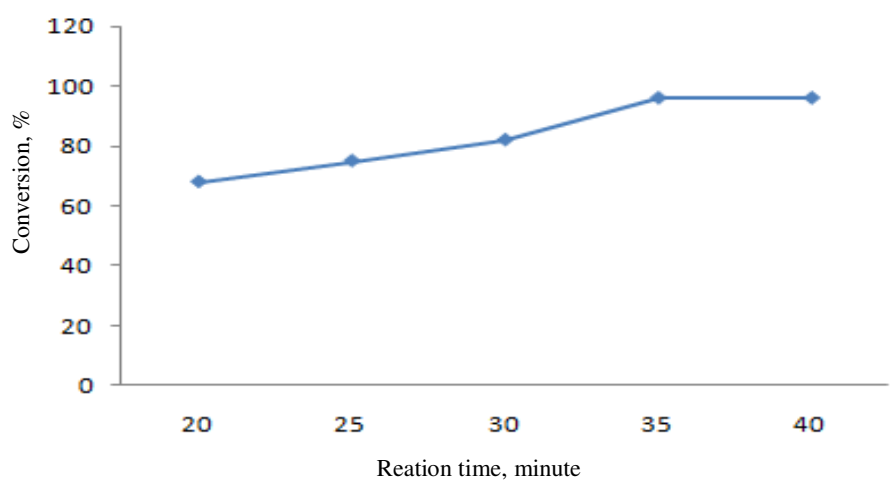

Figure 2. Effect of reaction time on fatty acid methyl ester production with a catalyst $(\mathrm{KOH})$ concentration $1.0 \mathrm{wt} . \%$ of oil (Reaction temperature $65^{\circ} \mathrm{C}$ and molar ratio oil:methanol 1:6)

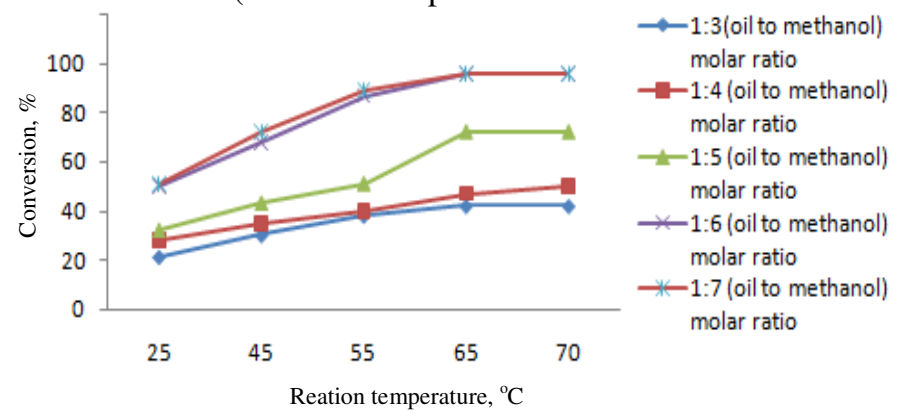

Figure 3. Effect of reaction temperature and molar ratio on fatty acid methyl ester production with a catalyst $(\mathrm{KOH})$ concentration $1 \mathrm{wt} . \%$ of oil, reaction time $35 \mathrm{~min}$

\section{Effect of reaction temperature}

The conversion of Jatropha curcas oil into FAMEs increases with reaction temperature. Experimental trials were carried out at $25^{\circ} \mathrm{C}$ (room temperature), $45^{\circ} \mathrm{C}, 55^{\circ} \mathrm{C}, 65^{\circ} \mathrm{C}$ and $70^{\circ} \mathrm{C}$. In all experiments oil to $\mathrm{MeOH}$ ratio was constant $1: 6$ and $1.0 \mathrm{wt} \% \mathrm{KOH}$ (as catalyst) were used (the optimal condition achieved in the previous section). The yield of methyl ester at room temperature and $55{ }^{\circ} \mathrm{C}$ were $30 \%$ and $76 \%$, respectively. The maximum conversion $96 \%$ is obtained at the temperature $65^{\circ} \mathrm{C}$. Figure 3 indicates the results of these experiments.

\section{Conclusion}

The experimental result of transesterification of Jatropha curcas oil indicates the optimal reaction condition: $1 \% \mathrm{KOH}$ as a catalyst (wt\% of oil), reaction temperature $65{ }^{\circ} \mathrm{C}$, oil: methanol molar ratio $1: 6$, reaction time $35 \mathrm{~min}$. at these optimized condition we got the maximum yield $96 \%$. The synthesized product meets ASTM specifications for biodiesel

\section{Reference}

1. Rao T V, Rao G P and Reddy K H C, Jordan J Mechanical Ind Engg., 2008, 2(2), 117-122.

2. Graboski M S and McCormick R L, Prog Energy Combust Sci., 1998, 24(2), 125164; DOI:10.1016/S0360-1285(97)00034-8

3. Paulo A Z S, Bryan R M, Brajendra K S and Sevim Z E, Fuel, 2009, 88(6), 11431147. DOI:10.1016/j.fuel.2008.11.017 
4. Fukuda H, Kondo A and Noda H, J Biosci Bioeng., 2001, 92(5), 405-416; DOI:10.1016/S1389-1723(01)80288-7

5. Kumar D, Kumar G, Poonam and Singh C P, Ultrasonics Sonochem., 2010, 17(5), 839-844; DOI:10.1016/j.ultsonch.2010.03.001

6. Kusdiana D and Saka S, Bioresour Technol., 2004, 91(3), 289-295; DOI:10.1016/S0960-8524(03)00201-3

7. Warabi Y, Kusdiana D and Saka S, Bioresour Technol., 2004, 91(3), 283-287; DOI:10.1016/S0960-8524(03)00202-5

8. Connemann J and Krallmann A, Process For The Continuous Production of Lower Alkyl Esters of Higher Fatty Acid, U.S. Pat. No. 5354878 A1.

9. Kumar G, Kumar D and Johari R, Ultrasonics Sonochem., 2014, 21(5), 1618-1623; DOI:10.1016/j.ultsonch.2014.04.004

10. Hanna M A, Transesterification Process for Production of Biodiesel, U.S. Pat. No. 0032826 A1.

11. Kumari A, Mahapatra P, Kumar G V and Banerjee R, Bioprocess Biosyst Eng., 2008, 31(4), 291-298; DOI:10.1007/s00449-007-0160-X

12. Kumar G and Kumar D, J Environ Chem Engg., 2013, 1(4), 962-966; DOI:10.1016/j.jece.2013.08.006

13. Kumar D, Kumar G, Johari R and Kimar P, Ultrason Sonochem., 2012, 19(4), 816822; DOI:10.1016/j.ultsonch.2011.11.004

14. Klofutar B, Golob J, Likozar B, Klofutar C, Zagar E and Poljansek I, Bioresource Technol., 2010, 101(10), 3333-3344; DOI:10.1016/j.biortech.2010.01.007 